\title{
Soil releasing as key to rethink water spaces in urban planning
}

Fulvio Adobati and Emanuele Garda*

\begin{abstract}
Soil sealing processes that involved European cities in the twentieth century have reduced the quantity and quality of permeable soils (open land for agricultural and leisure resources). These processes have also weakened the ability of urban areas to manage natural events, of all evidence regarding the water cycle. This intense phase was supported by a cycle of growth that showed signs of an irreversible crisis only in the last decade, starting a new and unprecedented season. However, soil sealing development constitutes the most intense form of land degradation and affects all ecosystem services (Tobias et al. in Land Degrad 29:2015-2024, 2018). This is particularly true for spaces and territories along main rivers where the presence of sealed areas and concrete channels (riverbed and riverbanks) represents a problem regarding hydrogeological, ecological, and landscaping aspects. To safeguard urban systems, by restoring "landscape river" (and its surroundings), increasing green areas and more efficient management of the rainwater, it is fundamental to enhance the "removing sealing layers" (EU 2012) according to a holistic approach. This paper explores the de-sealing concept and highlights some international and Italian cases, in particular the River Contracts experience promoted in the Lombardy Region, including actions proposed by public policies and urban planning tools. All these experiences have proposed de-sealing processes of river environments and urban systems ensuring a new integration between urban areas and "water landscapes". To underline some characteristics this exploration allowed: to highlight different de-sealing approaches, between direct or indirect conditioning; to recognize river elements and "environments" in which these initiatives are activated; to recognize in these initiatives a multi-scale attitude both the expected effects and the type of involved institutional subject involved; to identify the main subjects, with specific roles and responsibilities, in this type of process; to recognize limits and critical issues. River restoration, combined with de-sealing actions inside the urban structures, shall be performed by answering to several needs: increasing the green open space quantity and ecosystem services recovery; contributing to biodiversity by restoring ecosystems and ecological processes; balancing the soil-sealing negative externalities; improving the flood-risk mitigation and management in urban areas. In particular, the voluntary instrument of the River Contract includes a territorial area that is adequate for the treatment of the phenomenon but is struggling to be codified in the local planning instruments with cogency. The assumption of different spaces and the recognition of the same in the spatial devices of urban planning instruments could define more clearly the need to face the water-city relationship effectively, for the benefit of urban security and the quality of the inhabitants' living environment.
\end{abstract}

Keywords: Resilience, De-sealing, Urban river, Low-impact developments, Climate change

*Correspondence: emanuele.garda@unibg.it

Department of Engineering and Applied Science, University of Bergamo, Viale Marconi 5, 24044 Dalmine, Prov. Bergamo, Italy

\section{Introduction: a necessary reconciliation between water and city}

Water is the main morphogenetic agent in the characterization of landscapes (Perini and Sabbion 2017), and from the physical point of view, it represents the generating force of terrestrial morphologies (Chiesa 2005). This element should also be interpreted considering its aptitude 
to build links with the life of human societies (Pagani 2004) since it always played a substantial role in the relationship between human communities and nature:"an inescapable condition for life and the choice of the place of stay, water can build links with the vicissitudes of places and with landscapes, always becoming a relevant and often dominant subject" Pagani 2007: 5). This is a value that has long been considered and promoted at the international level, for example by the European Union through important acts such as the Water Framework Directive (Directive 2000/60/EC) which aims to encourage the sustainable management of freshwater resources (Carter 2007), considered water not "a commercial product like any other but a heritage to protect, safeguard and treat as such". This Directive has been inspired by numerous international initiatives that have focused on the management and conservation of natural resources, highlighting the importance of water resources and the need to protect them as crucial environmental elements of a territory (Voghera 2015). The United Nations Water Conference held in 1977 in Mar del Plata (Argentina), considered different themes and objectives, for example the evaluation of the state of water resources; to ensure that an adequate supply of quality water was available to meet the planet's socioeconomic needs; to increase water use efficiency; and to promote preparedness, nationally and internationally, so as to avoid a water crisis of global dimensions before the end of the twentieth century (Rahaman and Varis 2005). The International Conference on Water and Environment held in Dublin in 1992, the so-called Dublin Principles (Scaduto 2016), was the first to underline the different roles of water resources and the importance of political and social guidance and consciousness. In addition to the proposal for some guiding principles for the local, national and international levels, hydrographic basin-based integrated management was another important result of this initiative analyzed through a new holistic approach including forms of governance and stakeholder participatory actions, so as to take their effects from both economic and social perspectives (Teodosiu et al. 2003; Rahaman and Varis 2005; Molle 2006). That same year, the World Water Day (March 22) was established by the United Nations Conference on environment and development in Rio de Janeiro, held as part of the initiatives on sustainability (Rio Declaration on environment and development). Moreover, as Voghera (2015) has effectively synthesized, world forums on water issue were organized from 1997 onwards as international events to discuss the multiple issues involving water resources: in Marrakech (1997), water and sewerage systems, shared management of water resources, conservation of the ecosystem, and efficient use of water; at the Hague (2000), water and nature, water and people, water and sovereignty; in Tokyo (2003) and in Mexico City (2006), the relationship between water resources and people's lives, new policies, integrated resource management, efficient management, and stakeholder involvement; in Istanbul (2009) changes in water consumption policies (especially in the agricultural sector), the struggle against subterranean water pollution, and improvement in sewage treatment plants.

The issue of water management has been given more attention, not only because it refers to the physical component of natural systems, but because it is fundamental for the quality of life of communities (Voghera 2015).

These considerations apply especially to the rivers that have always been at the center of the life of cities, but that need to be "controlled" to be able to build human societies (Petts et al. 2002). Both ancient and modern communities have benefited from the presence of rivers and took advantage of them for a long time (Darby and Sear 2008). In recent centuries, mankind has altered the river corridors and their surrounding areas through over-engineering works, pollution, exploitation of natural resources, and ineffective management (Nienhuis and Leuven 2001). Especially in the last century, watercourses have been artificialized to support settlement growth and maximize the exploitation of urban soils (Perini and Sabbion 2016). However, despite the ongoing attempts to tame rivers inside the urban environments, cities have never been able to completely control and dominate them, as witnessed by the recurring floods and other natural disasters (Knoll et al. 2017). Moreover, the unsuccessful attempts to reconcile interactions between nature and human society and to protect the population from uncontrolled hydraulic dynamics made the conflict even worse (Knoll et al. 2017).

The overall negative picture caused by the artificialization of rivers has also been aggravated by land take actions $^{1}$ that affected urban systems in recent decades. In addition to considerably interfering with the main characteristics of land, soil sealing ${ }^{2}$ has increased the contrast between its functions (Bouma 2006), determined by the environmental effects (Ferreira et al. 2018) which proved to be "forces" of global relevance (Foley et al. 2005). The negative effects concerned the loss of biodiversity; climate and microclimate variations (Pauleit et al. 2005),

\footnotetext{
${ }^{1}$ It can be defined as the loss of soils (agricultural, forest, semi-natural and natural soils) due to urbanization and soil artificialization processes. This also includes land cover due to buildings and construction of urban infrastructures, as well as green areas or sports and entertainment facilities (EEA 2006).

2 It means the permanent covering of a surface through the creation of impermeable artificial materials (EU 2012).
} 
heat island effect (Scalenghe and Marsan 2007); finally, the impacts on food safety (Gardi et al. 2015).

The increase in impermeable surfaces, with an impact on the hydrologic cycle (Haase 2009; Depietri et al. 2012; Gibelli et al. 2015) and water quality (Miller and Hutchins 2017), has contributed to the increase of water evaporation in the atmosphere, changes in rainfall distributions, changes in soil water content and surface runoff, with consequent changes in infiltration and groundwater replenishment (Vurro et al. 2007). The artificialization of the territory has determined (Gibelli et al. 2015): a reduction in the time of rainwater concentration; the intensification of flood events; a reduction in infiltration water supplies for groundwater replenishment; the increase in surface flow (run-off), with a consequent increase in soil erosion, sediment transport, and water pollution; the creation of wastewater collection networks which, to be technically sustainable, require greater complexity (in contrast with the ease and cost of management.)

Even the accelerated climate changes (Rosso 2017) have made the situation worse, by increasing the risk of flooding, altering the distribution, frequency, and intensity of extreme climate events (Fini et al. 2017; Milly et al. 2002). Therefore, water resources are particularly sensitive to changes in atmospheric events and anthropic pressure (Vurro et al. 2007) produced by soil sealing (Artmann 2014).

Within this general framework, it emerges the need to contrast some critical issues produced by the artificialization and soil sealing, redefining the relationship between city and river. A possible solution ${ }^{3}$ is the promotion of multiple de-sealing processes in contexts characterized by the presence of urban rivers, with the consequent restoration of soils. Through a "removal project" (Terranova 1997) consisting both of the arrangement of the areas crossed by the rivers and of the planned objectives of the Agenda 2030 for Sustainable Development of urban areas, it will be possible to restore a part of the conditions lost in the growing season (Lanzani 2014). Thanks to this type of design process, which requires a multiscale (Casti 2013) and a holistic (Francis 2012) approach due to the specificity and variety of the treated elements, the minimum conditions can be created to implement the management capacity of certain problems, improving the resilience of urban systems.

Therefore, the restoration of rivers and streams territory is possible, as well as desirable (Grant 2016), since the reduction of the amount of water directed towards

\footnotetext{
${ }^{3}$ This choice is also based on the common awareness that considers urbanization as one of the most dramatic and dynamic causes of the alteration of ecosystems (Grimm et al. 2000; Pickett et al. 2001) and soil sealing as a soil degradation factor (Ferreira et al. 2018; Fini et al. 2017).
}

watercourses from the surrounding environment can contribute to limit certain risk conditions and also making it possible to recover the watercourses spaces for other purposes. In general terms, the reintroduction of plant systems through the strengthening of green and blue networks-conceived as ecological infrastructures integrated with the surface water cycle-can support the decrease in hydraulic risks by reducing, for example, flooding in urban areas and helping to limit overflowing in river contexts (Sturla and Di Chiara 2017). Overall, these initiatives can be included in the recommendations proposed by the Guidelines on best practice to limit, mitigate or compensate soil sealing by the European commission or connected to the objectives of Horizon 2020 for sustainable management of natural resources towards a society more resilient to climate changes. This theme is part of the 2030 Agenda for Sustainable Development, particularly in Goal 11 "Make cities inclusive, safe, resilient and sustainable" ${ }^{4}$ and Goal 13 "Take urgent action to combat climate change and its impacts". Finally, these principles align with Directive 2007/60/EC (the "Floods Directive") that referred to the need of "giving rivers more space", through flood risk management plans, including "maintenance and/or restoration of floodplains, as well as measures to prevent and reduce damage to human health, the environment, cultural heritage, and economic activity".

Recovering breathing space for the river and water, therefore, implies policies aimed at restructuring of the physical city, placing as a fundamental factor the search for a balance between construction and green spaces, from the perspective of a city conceived as a "sponge".

In the following two paragraphs the theme of desealing will be analysed and investigated through some experiences promoted at the international level, in contexts affected by significant soil sealing processes. These different experiences, which the authors have organized within some categories, testify both the recognition of the different purposes sought with desealing practices, especially for the improvement of water management in urban areas, and the multiple nature of the spaces affected by these practices. The taxonomy that emerges from the various experiences described underlines the need to adopt

\footnotetext{
${ }^{4}$ Mostly: 11.3 "By 2030, enhance inclusive and sustainable urbanization and capacity for participatory, integrated and sustainable human settlement planning and management in all countries"; 11.b "By 2020, substantially increase the number of cities and human settlements adopting and implementing integrated policies and plans towards inclusion, resource efficiency, mitigation and adaptation to climate change, resilience to disasters, and develop and implement, in line with the Sendai Framework for Disaster Risk Reduction 2015-2030, holistic disaster risk management at all levels".

5 Mostly: 13.2 "Integrate climate change measures into national policies, strategies and planning".
} 
a holistic approach especially within the urban systems affected by the presence of urban rivers. The concluding paragraphs are dedicated to the treatment of a specific territory, affected by the presence of watercourses compromised by urban growth, which have seen the introduction of River Contracts. Finally, the conclusions will lead to the search for a link between the desealing actions and the River Contract promoted in the Italian context.

\section{Background: re-writing the city and re-covering the land}

The reactivation of the conditions inhibited by urbanization processes is supported by soil de-sealing practices. De-sealing means removing sealing layers such as asphalt or concrete, loosening the underlying soil, removing foreign materials (EU 2013), and restoring impaired soils (Tobias et al. 2018). The benefits that can be obtained from this type of activity can concern: (i) to improve the hydraulic performances of territories affected by these interventions; to increase the capacity of urban systems to manage rainfall events by restoring soil infiltration (Brears 2018); (ii) to restore soil ecological function by creating opportunities to reintroduce vegetation ensuring an "ecological reconciliation" (Rosenzweig 2003; Francis and Lorimer 2011); (iii) to increase the availability of green areas, also because of the benefits that these spaces can guarantee to the inhabitants (Chiesura 2004; Wolch et al. 2014; Kabish et al. 2015).

De-sealing actions can be found in a wide and multiform set of initiatives promoted in many international contexts that, due to some specific conditions and general characteristics, can be ascribed to some macro-categories (Garda and Adobati 2018, Adobati and Garda 2019). ${ }^{6}$ The definition of this range of actions finds support in the different reasons that have determined and sustained the start of these initiatives (ecological compensation, etc.) and in the importance attributed to desealing with respect to the desired results.

It is also important to consider the different contexts, and the characteristics of the site, in which these actions have been applied, (legal status, previous use destination, the presence of contaminations, etc.). Finally, it is important to consider the technical and regulatory tools to implement de-sealing operations.

First, these actions resulted in the removal of sealed surfaces or buildings to be used as environmental

\footnotetext{
${ }^{6}$ Alongside this condition - a priority in the re-reading of these experiences - other issues must not be underestimated, for example, the different contexts in which these actions have been applied, or the characteristics of the area prior to the de-sealing intervention (for the legal status, the land use prior to the implementation of operations, the presence of contaminations, etc.). Finally, the type of legitimation tool and the profile of the promoter are other critical issues.
}

compensation for new urbanization projects. Such mechanisms have been considered in the Walloon Region (2005), thanks to the application of the no net land take concept (EU 2016) to urban development plans. Germany also has significant experience in implementing these principles (Pileri 2007), especially in the activation of de-sealing interventions at regional (e.g. in the BadenWürttemberg region) and local level (Stuttgart and Berlin). The city of Dresden, for example, after the flooding of the Elbe River (2002), introduced the "account for land cover/use compensation" including, among the compensatory measures, greening or de-sealing actions which involve unused and abandoned areas. ${ }^{7}$

Second, the redevelopment of brownfield sites, as well as having built a complex issue with which public and urban policies have confronted for many years (Atkinson et al. 2014), has suggested some ways for the increment of permeable open spaces. In these second set of actions, de-sealing has emerged as a resul-often secondary-of the spatial redesign and relocation processes. These were initiatives that, through the re-modulation of the coverage ratios and the deep scraping, have increased the permeability and the availability of green spaces. At the end of the eighties, Denver's decision to build a new and more appropriate airport prompted the local administration to dismiss and regenerate the area on which the previous plant was located. With the support of the institutions and some important local stakeholders, the recovery project (Stapleton Development Plan) was approved. This project, in accordance with the principles of New Urbanism, guaranteed the creation of a new settlement, increasing permeable surfaces and restoring the river, previously located underground beneath the airport (Grant 2012). Various urban projects have been promoted and carried out in Europe. In Denmark, for example, with the Godsbanearealet (Aalborg) project, a former large railway yard (about 30 hectares) has been redeveloped and replaced by a new eco-district through a project based on the search for high performance in terms of adaptation to climate changes. In the new open spaces, many sustainable urban drainage systems have been introduced. These systems find a place in a transformation process that has doubled permeable surfaces area (for around 15 hectares). Similar experiences have also been carried out in Berlin, Paris, Lyon, and Grenoble, always combining the search for better management of rainwater in urban contexts with the increase in soil permeability.

\footnotetext{
${ }^{7}$ From 2000 to 2015 the interventions included in this initiative have determined the de-sealing of about 36 hectares. Real estate companies were given the opportunity to decide whether to carry out such interventions or, alternatively, to pay the related charges to the municipal environmental authority to implement the interventions.
} 
Third, the concept of "incongruous buildings"; introduced in 2002 by Emilia-Romagna Region (Italy), giving municipalities the possibility of removing these "environmental detractors" (Stanghellini 2010) as critical elements from an ecological and landscape-related point of view. After Emilia-Romagna, other Italian regions also acted with the same goal, even though with different purposes. The Liguria Region, for example, has given the possibility to demolish buildings to reduce exposure to hydraulic risk. In this case the incompatibility has been evoked to emphasize an incorrect location due to other reasons such as the difficult coexistence between human activities and rivers, caused by incorrect past urban planning choices. The delocalization of buildings due to incompatibility with the environmental conditions represents a recommended solution to include buildings and settlements. ${ }^{8}$ These are initiatives that, by operating through the relocation of built-up areas, ${ }^{9}$ can activate partial or total demolition processes ${ }^{10}$ creating the conditions for a new soil permeability and for strengthening ecosystem services. ${ }^{11}$

The fourth set of experiences is more clearly related to the effects of soil sealing on the water cycle, since the increase of coverage rate in urban areas is connected to the increase in surface runoff, to the water quality deterioration (Dietz 2007) and to the reduction of soil infiltration processes (Ahiablame et al. 2012). For these reasons, the inadequacy of traditional methods of water management in urban areas has led to the emergence of new techniques ${ }^{12}$ which for several years have been at the center of the EU debates and policies (Masseroni et al. 2018). Soil unsealing (Tobias et al. 2018), in this case,

\footnotetext{
${ }^{8}$ Historical examples of permanent relocation of communities concerned the city of Allenville in Arizona which in the $1980 \mathrm{~s}$ was transferred due to the flood risk caused by the presence of a large river. Generally speaking, it should be noted that the permanent transfer of communities away from risk areas has long been considered an important "non-structural" option, supported by the emergency management authorities around the world (Perry and Lindell 1997).

${ }^{9}$ In the operational perspective suggested by Lanzani (2013), relocations can be applied to respond to multiple needs, dealing with different geographic features: along with the river flooding areas; within areas of landscape value; close to infrastructures with significant noise impact; in situations that due to excessive dispersion cause mobility problems.

${ }^{10}$ In Italy, the relocation process concerned the mitigation of risks, such as hydraulic risk, becoming part of the passive measures. This type of initiative, supported by PAIs and the "Floods Directive", is still a rather limited option. A 2016 study found that only 4\% of Italian municipalities analyzed (around 1300) had implemented the relocation of buildings (Legambiente 2016).

${ }^{11}$ For an analysis of this complex concept, especially for the spatial planning implications, see Costanza et al. (1997), De Groot et al. (2002), Wratten et al. (2013), Ronchi (2018).

${ }^{12}$ On the international level, these techniques have been referred to under different names, for example Low-Impact Developments, Best Management Practices, Green Infrastructure, etc.
}

is used to enforces the principles of sustainable urban drainage. This applies, for example, to rain gardens, vegetated areas characterized by slight soil depressions, which, by intercepting and retaining rainwater allow the subsequent and gradual water infiltration (Gibelli et al. 2015). In Germany, where urban drainage techniques have been used for decades (Nickel et al. 2013), these issues are widespread, as in many other European ${ }^{13}$ and non-European countries (Masseroni et al. 2018). In Singapore, a territory characterized by extreme climatic conditions, the National Water Agency has supported the $A B C$ Waters initiative (2006) to promote the integration between the environment, water bodies and communities, proposing, for example, guidelines for the definition of masterplans integrated with the themes of sustainable urban drainage (PUB 2018). ${ }^{14}$ In August 2011 the Copenhagen City Council, after the climate summit COP15 (2009) and some extreme rainfall events (2010 and 2011), adopted its climate adaptive measures plan (Copenhagen Climate Adaptation Plan). The Cloudburst Management Plan, an offshoot of the Copenhagen Climate Adaptation Plan, outlines the methods, priorities, and measures recommended for the area of climate adaptation including extreme rainfall. This Plan is characterized by the definition of open spaces regeneration interventions and includes 470 neighborhood-scale projects that meet adaptation goals such as water drainage, collection and conveyance, and the integration of blue and green infrastructures (D'Ambrosio and Leone 2015).

Finally, it is possible to recognize a fifth set of experiences that have assumed and applied the principles of permeabilization and restoration of soils to the specific category of spaces dealt within the following sections. By analysing different experiences, it is possible to recognize a common feature of attention to river restoration, with interventions aimed both at restoring the hydraulic balance and at the ecological and landscape qualification of the river environment.

\section{A path for river rehabilitation}

The artificialization processes of riverbeds and flood plains, that have long been promoted as a method for managing areas crossed by rivers, led to a decline in the quality of these ecosystems by reducing the dissipation of water energy in the event of a flood. However, in the last decades "urban rivers" faced an important change: after being long considered neglected and abandoned spaces, they have been revalued and reconverted, becoming the

\footnotetext{
${ }^{13}$ In Italy these issues are part of a debate that is playing a growing role in the framing of legislation.

14 These tools have influenced about 30 projects completed in 2018, but it is expected to reach around 100 by 2030 .
} 
most prestigious places of the cities (Prominski et al. 2012). The interest in the recovery of rivers, thanks to their intrinsic value and their ability to provide ecosystem services (Lemmons and Victor 2008), has benefited from a growing awareness that the restoration of the natural water cycle can contribute to fighting climate change in urban areas (Brown et al. 2009).

Regeneration and renaturalization interventions of river areas are part of a large set of principles, experiences, and methodologies increasingly being used to replace traditional approaches for the hydraulic management of rivers. River restoration refers to some techniques and activities that have emerged in many international contexts to meet different needs (Clewell and Aronson 2006). In recent decades, since the river recovery processes were started, different methods have been used. These included both idealistic approachesaimed at protecting the landscape heritage - and realistic approaches instead aiming at ensuring the improvement of the integrity of rivers (hydrological, geomorphological, ecological, etc.) without removing human presence (Gonzalez et al. 2012). Under optimal conditions a watercourse is able to self-regenerate, metabolizing contaminants, unlike what can happen in an anthropized environment, where this process cannot take place due to poor ecological and biological conditions (Perini and Sabbion 2016). Furthermore, the rivers reactivation, "space to water" restitution, recovery of biodiversity, and restoration of the native flora through the modification of the physical structure of soils, can affect soils' water storage, infiltration, and evaporation capacity (Grant 2016).

In this path of rebirth, the renaturalization process carried out through the removal of physical structures and the subsequent reintroduction of some characteristic features of river environments have been widely implemented in different geographical contexts.

Following a brief review of cases to describe the actions developed in different contexts for a rehabilitation of river contexts in urban areas.

In the Sixties, the city of Seoul, in a period of significant growth and urbanization, decided to put underground the Cheong Gye Cheon ("clear water of the valley" in the original language) canal, that from east to west crossed the entire metropolitan territory. The surface areas resulting from the covering of this ancient canal, built in the 14th century to support the main existing streams, were used to build a large road network in the early 1970s. In the early 2000s, after three decades of operation of this infrastructure, thanks to the impetus given by the Mayor of Seoul (and important public funding), the process was initiated that within 2 years led to the dismantling of the infrastructure and the partial restoration of the river (for about $6 \mathrm{~km}$ ). This reactivation process involved both the riverbed section and the flood plains, leading to the creation of $a^{15}$ metropolitan linear park (Mariarinaldi 2007).

In Houston the Buffalo Bayou river, which can be considered the main metropolitan drainage system and an element of dialogue between built-up areas and urban ecosystems, has been included in an ambitious regeneration project (Buoro 2019) which has been widely implemented over the years. Formerly used by Native Americans as a campsite, this hydraulic system became, at the end of the eighteenth century, an important corridor of culture, social activities, navigation and transport (Hung et al. 2011). During the nineteenth century this reality experienced an intense urban development that led to the progressive occupation, waterproofing, and artificialization of the river areas. The recovery process of these areas, supported by the Buffalo Bayou Partnership, has been activated in 2001 with the drafting of a Masterplan that has given ample evidence to the issues of renaturalization and reduction of environmental risks. Among the different strategies proposed by the plan, it emerged the need to: rehabilitate the ecological functions, also in relation to the infiltration and rainwater drainage capacity; increase the flood management capabilities; promote sustainable urban drainage measures. In the US context, in the last few years other projects for the renaturalization of watercourses in highly urbanized areas have been activated. This happened also for the Bronx river, whose regeneration process was started after the first interventions in the seventies promoted by local associations. In a context in which soil sealing led to the increase of the surface runoff of rainwater towards the watercourse (Perini and Sabbion 2016), restoration of river environments techniques has combined with integration measures with existing parks and with brownfield sites reconversion projects. The Concrete Plant Park, for example, is a park located on the riverbank opened to the public in 2009 that retains only half of the previous building structures of an abandoned industry (1987).

Similar results have been achieved in several projects implemented in the European context. The Birsa river in Basel, after having undergone a continuous artificialization process throughout the nineteenth century, was included in a partial renaturalization project (between 2002 and 2004) for a stretch of about $1.5 \mathrm{~km}$. In addition to including actions to improve water quality, the recovery intervention involved removing the concrete structures in the riverbed. The course of the river has been modified through the widening of the riverbed section and the introduction of water redirection systems (for

\footnotetext{
${ }^{15}$ In such a reality characterized by a lack of availability of public green areas, this was a very important initiative, though not without criticality (Cho 2010), but able to redefine and enhance the river environment.
} 
better water management). In Germany, a long and complex process for the redevelopment of the Emscher river started in the 1990s, within what was once Europe's largest industrial area (Prominski et al. 2012). The problems of this river involved both its more than 10-years use as a "dump" for the Ruhr area, and the high level of urbanization and sealing of the surfaces in the surrounding areas. This caused issues in the management of rain waters and alterations in the hydraulic cycle (Perini and Sabbion 2016). In particular, the restoration of the Emscher river has been carried out through a series of multiannual interventions (1990-2020) based on three themes: (i) the creation of a decentralized water and wastewater treatment system; (ii) the separation of rainwater and wastewater; (iii) the renaturalization of rivers and flood plains by removing existing building structures. These interventions have also been used to increase the hydraulic performance of the soils (improving the relationship with climatic events).

The review of mentioned cases highlights the plurality of design themes for river spaces, due to the geographical characterization and sensitivity gained in the various contexts. This panorama allows us to place the themes at the centre of the case study of the Lombardy Region treated in the following chapter. The Lombardian laboratory is in fact of particular interest for the historical, environmental, and landscape richness of the hydrographic network that innervates the metropolitan system, and for the complexity of the problems that have arisen with the consistent, and often disordered, settlement growth.

Disputed spaces: themes and projects in Lombardy Region In the Italian territory, and in particular in the Lombardy Region, the themes mentioned in the previous sections are being slowly transposed thanks to some initiatives on a local and regional scale. ${ }^{16}$ From a technical and cultural point of view, a significant contribution was given by the activation of some River Contracts. ${ }^{17}$ These are voluntary tools for strategic ${ }^{18}$ and negotiated planning which, through correct management of water resources within the river basins ${ }^{19}$ (Bocchi et al. 2012), can guarantee to

\footnotetext{
${ }^{16}$ In recent years, a new season of urban regeneration and soil sealing laws, approved by the Italian Regions (e.g. Lombardy, Veneto, Piemonte, and Liguria), have provided for specific regulations to promote desealing processes.

17 These tools pursue the objectives of environmental legislation, in particular the 2000/60/EC (Water Framework Directive), 2007/60/EC (Floods Directive), 42/93/EEC (Habitat Directive) and 2008/56/EC (Marine Strategy Framework Directive) directives.

${ }^{18}$ It is important to underline that with the polysemic expression "strategic planning" (Mazza, 2013), a broad set of concepts, procedures and tools can be identified (Albrechts 2004; Sartorio 2005).

19 The river basin, besides playing a "pivotal role not only in the water cycle, but also in nearly all other life cycles as a crucial source of bio-diversity" (Jaspers, 2003, 78), has long been assumed as the optimal territorial envi-
}

safeguard from flood risk, promote the enhancement of river contexts thanks to the involvement of a wide network of regional and local institutional stakeholders. The River Contracts are a governance institutional processes at the local level that involve all the main actors of the area in the identification of integrated actions of river environmental policies. They can also be considered both as a response to the needs of a community of users (Rosillon and Lobet 2008) and a valuable resource for the development of territories (Berruti and Moccia 2016). River Contracts (Contrat de Rivière) were established in France in 1981 (Brun 2014) as programs, focused on stakeholder consultation, for the medium- or long-term rehabilitation of rivers, lakes, aquifers, and river mouths (Scaduto 2016). In the following decades they have become a key tool for French integrated water resources management policies and a reference approach for the requalification of rivers at basin scale (Brun and Marette 2003; Brun 2010). Between 1990 and 2000 about 200 river contracts were promoted in France (Brun 2014), underlining their wide dissemination and importance for this geographical and political context. After the first French experiences, River Contracts have spread to many other European countries (Belgium, Netherlands, Spain, Italy, etc.) also involving cross-border territories and river basins (France, Spain, Belgium, Switzerland, etc.).

In the European context, River Contracts have been an outcome of the decentralization processes at the institutional level, promoted, since the 1980s, by the European Community as a response to growing institutional fragmentation (Sancy 2008).

With the Second World Water Forum in The Hague (2000), the River Contracts was identified and defined as an instrument that allows adopting a system of rules in which public interest, economic performance, social value, and environmental sustainability are equally effective in finding solutions for the redevelopment of a river basin (Scaduto 2016). This important definition represented a step forward in terms of applicability compared to the concept of integrated water management defined in Dublin in 1992 at the International Conference on Water and Environment (Brun 2010).

Inspired by the international experiences and debate, the Italian River Contract ("Contratto di Fiume") is not based on an institutional law (Voghera 2015). It is more the result of an experience implemented and developed in the last years and constantly consolidated both methodologically and operationally.

\footnotetext{
Footnote 19 (continued)
}

ronment for the management of water resources (Choukr-Allah et al. 2012), to become "a political and ideological construct" (Molle 2006: 23). 
The experimentation that was started in Italy saw, after the signing of the first River Contract ${ }^{20}$ and the diffusion of these instruments throughout Italy, the birth of a specific working group (2008) that represented the Technical-Scientific Direction of the National Table on River Contracts. As Alberto Magnaghi pointed out, on the whole, it was a broad "movement" of the national level that saw local administrators, public executives, officials, scholars, and associations, competing in a passionate debate "in the awareness of all that an important game was being played in the renewal of the forms of government of the territory and the rebirth of a water civilization, in the increased awareness of water as a common good" (Magnaghi 2008: 89).

From the legislative point of view, a first important contribution came, at the regional level, from the Lombardy Region, which in 2003 approved Law number 26 ("Discipline of local services of general economic interest-Regulations on waste management, energy, subsoil use and water resources"), giving an initial institutional and regulatory recognition to River Contracts. ${ }^{21}$

Related to the national legislation, it is interesting to note that in 2015 with the modification to the Italian Legislative Decree n.152/2006, the River Contracts was defined as devices for the implementation of district planning instruments at basin and sub-basin level. This integration has also recognized them as "voluntary instruments of strategic and negotiated planning that pursue the protection, proper management of water resources and the enhancement of the river territories, together with the protection from hydraulic risk, contributing to the local development of these areas". The law that led to this important innovation comes after the efforts done by the National Table of river contracts to prepare the National Charter of river contract (2010) and the quality requirements of river contracts (March 2015) in a workgroup organized by the Ministry of Environment, Sea and Land Protection (Berruti and Moccia 2016) (Fig. 1).

\footnotetext{
${ }^{20}$ The Olona-Bozzente-Lura River Contract, signed in 2004 in the territory of the Lombardy Region, was the first Italian example. This is a first important experience, mentioned in the following paragraph, which benefited from the Region's participation in the project, included in the INTERREG IIIB CADSES 2000-2006, Netwet 2 Water Telematic Platform program.

21 In its original version, Article 45 recognized the River and Lake Contracts as the instruments of negotiated planning aimed at "promoting the consultation and integration of policies at basin and sub-basin level, with the participation of public and private entities, for the protection and enhancement of water resources and related environments and the protection from hydraulic risk".
}

In the western sector of the Lombardy Region, ${ }^{22}$ the area rich in watercourses between the Adda and Ticino rivers has been deeply marked by urbanization and soil sealing processes. Within the multi-centric conurbations that characterize the Milan urban region, ${ }^{23}$ the settlement growth has taken land from the rivers and compromised their role, making them in certain cases "neglected spaces". Some River Contracts were signed in the early $2000 \mathrm{~s}^{24}$ to respond both to the requests already emerged in the 1990s-following the first debates on the Lambro, Seveso, and Olona (Magnaghi 1995) river basins-and to the objectives set by the European Community in the field of water policy.

Among the River Contracts activated in Lombardy, the Olona-Bozzente-Lura ${ }^{25}$ River Contract contains some elements consistent with the topics of this paper. The strategic targets, foreseen by the Framework Agrement and signed by several local, regional and supra-regional institutional subjects, concern: (i) containment of water pollution; (ii) reduction of the hydraulic risks; (iii) environmental, landscape and ecosystem recovering; (iv) information sharing and dissemination about water culture. Different actions have been recognized for these targets which, by seeking to reconstruct the relationship between rivers and urban systems, have given first partial anticipation of the de-sealing and spaces permeabilization topics.

For example, the need to favor the "waterproofing" of urban areas was indicated to prevent hydraulic risks (second strategic target), also by relocating existing buildings (Fig. 2).

Different actions have been related to the third objective, for example the re-naturalization of the river (riverbed and riverbanks) and its linear and natural systems, the re-use of the brownfields by seeking the

\footnotetext{
${ }^{22}$ Located in the North of Italy, between the Alps and the Po river, Lombardy Region represents a particular geographical and administrative context. With a surface area of about 24,000 square kilometers and almost 10 million inhabitants, it can be compared to a nation. For the population, it is the 3rd most populated region in Europe after Île-de-France and Baden-Württemberg. This territory is divided into eleven provinces, one metropolitan area (Milan) and 1507 municipalities.

23 In the last decades this complex territorial figure has been analyzed and interpreted by numerous authors (e.g. Dalmasso 1972; Boeri et al. 1993; Clementi et al. 1996; Bolocan 2009; Balducci et al. 2016).

24 To date, the Olona-Bozzente-Lura River Contract (2004), the Seveso River Contract (2006), and the Lambro River Contract (2012) have been signed.

25 The River Contract was signed in 2004 by the Lombardy Region, Agency of Environmental Protection (ARPA) of Lombardy, Provinces of Milan, Varese, Como, Po River Basin Authority, Interregional Agency for the Po River (AIPo), Regional School Office of the Lombardy region and 78 municipalities included in the three river basins. Regional Parks, Local Parks of Supra-municipal Interest (PLIS), and some private stakeholders such as the Consortium of the River Olona and Carlsberg Italy have also joined.
} 


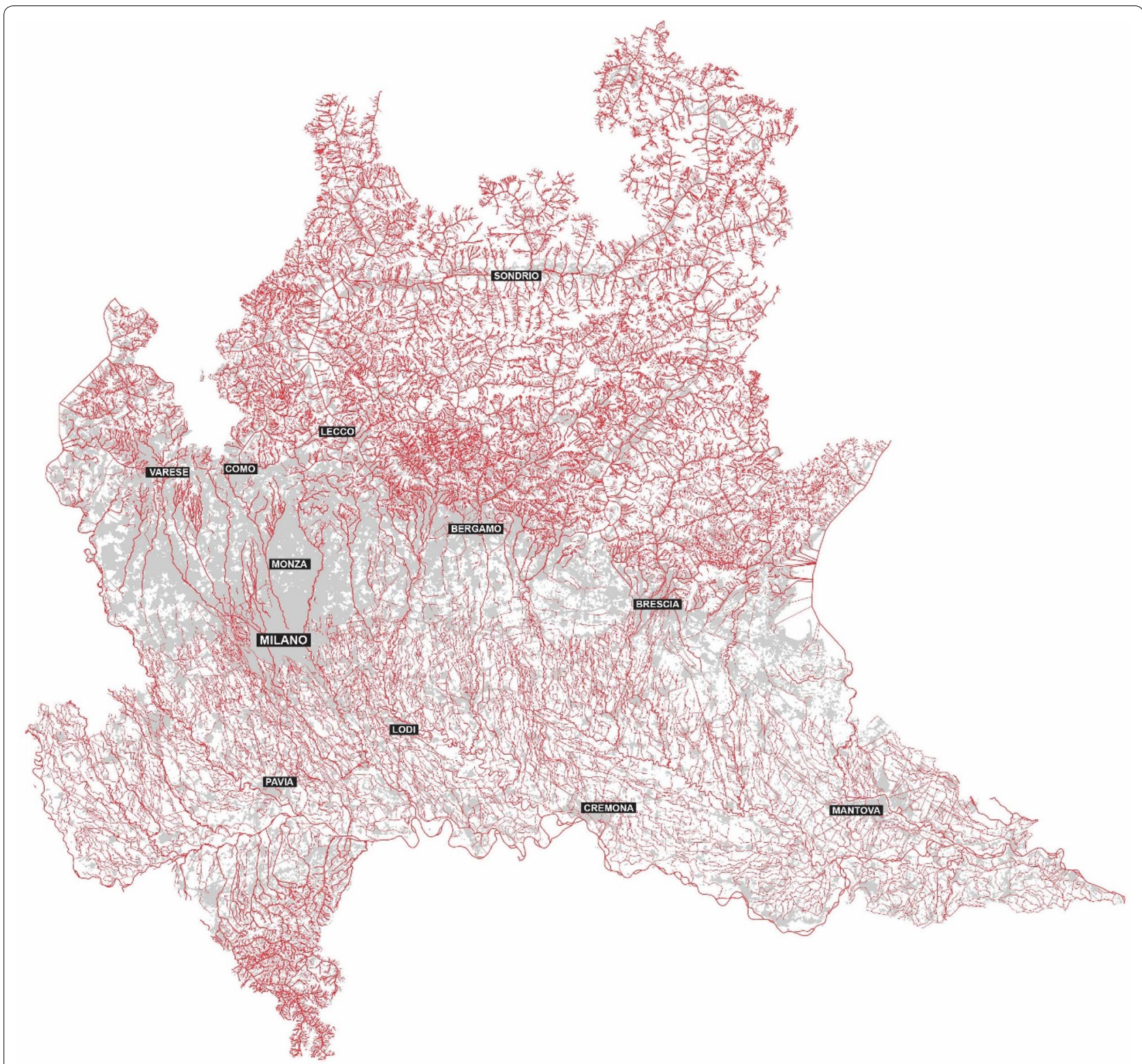

Fig. 1 The complex rivers network that characterizes the Lombardy Region (Source: Geoportale Regione Lombardia/elaboration of the Authors)

"river-territory relationship", the transfer of incompatible functions and buildings (for individuals and economic activities safety), or the choice of different patterns settlement limiting the occupation of the land (freeing open spaces). Thanks to this important initiative, the first of its kind for this regional context, in the following years the hypothesis of developing a Strategic sub-basin project for the Lura river was born, as required by regional regulations (in particular article 55 bis of the Regional law 12/2005) (Fig. 3).

Alongside the three macro-objectives of the more specific Strategic sub-basin project of the Lura river
(2015), concerning the improvement of the quality of the aquatic and peri-fluvial environment, the hydraulic risk mitigation and the improvement of the relationship between man and river, some guidelines are planned to influence political decisions of the local authorities. Among these orientations, interventions were also included to delocalize "anthropic activities" (Flood Safety macro-objective) located in the river flooding areas, in addition to dismantling and soil de-sealing measures to restore some of the river functions. These non-structural measures relate directly to the targets and key actions of Directive 2007/60 EC (e.g. "giving 


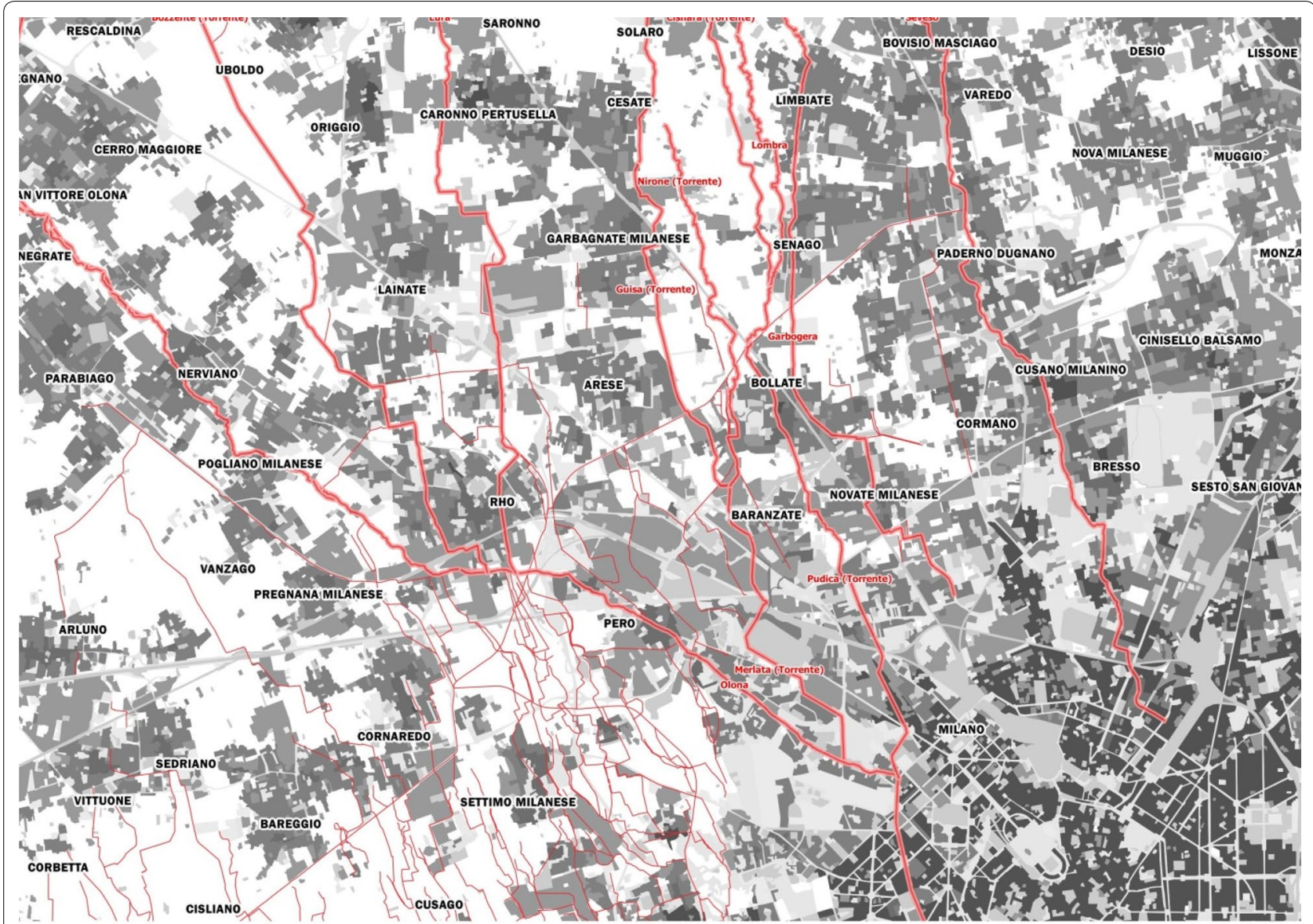

Fig. 2 Rivers networks in the Milan North-West urban area (Source: Geoportale Regione Lombardia/elaboration of the Authors)

rivers more space"), providing for the removal of vulnerable elements from areas subject to flooding and transferring them to areas with reduced risk.

For implementation and effectiveness of the proposed guidelines, the strategic sub-basin project, in addition to providing for the activation of "structural interventions" and the promotion of projects for the ecological recovery of the river, stresses the need to directly involve the local authorities. The local scale is considered optimal to provide real opportunities for action with attention to land functions, soil stratigraphy, and interactions with groundwater. Therefore, it is important to stimulate a constant integration of the hydraulic themes and the relationship between society and water within the municipal urban development plans and their variants.

Within this strategic project the de-sealing topic emerges due to the strong implications with the entire water cycle, compared both to its management during rainfall events, and to the risk aspects associated with the river (Fig. 4).
In general, the suggested targets are compared with the main "components" present in the Lura territorial system (riverbed, riverbanks, floodplain areas, and adjacent urban spaces) suggesting interventions of: (i) re-naturalization of the waterproofed rivers sections (considering also the secondary rivers) and of the neighboring surfaces; (ii) delocalization of buildings and human activities located in river flooding areas, through land redevelopment and de-waterproofing operations aimed at restoring space to the stream and its original functions; (iii) Sustainable urban drainage systems (reducing surface runoff and increasing time of concentration) to be activated in urban development processes, in redevelopment processes of existing patterns or in redesign processes of public spaces. While waiting for the goals introduced by the River Contracts to be adequately implemented into the urban planning tools, it is nevertheless possible to recognize in some local experiences a preview of the relationship between the city and the river. The Comprehensive Plan (Piano di Governo del Territorio-PGT) of some local authorities, even though with different 


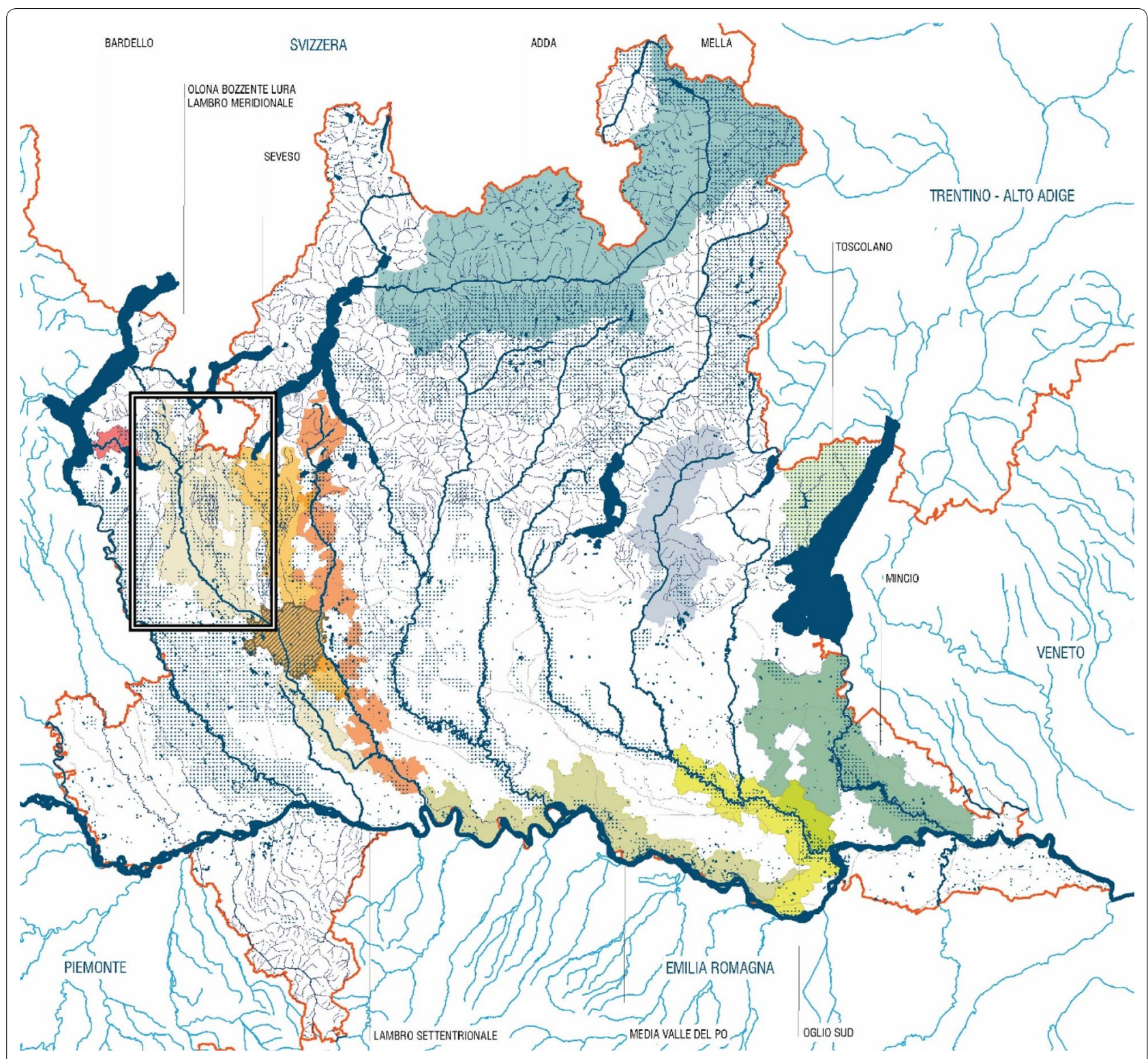

Fig. 3 The River Contracts geography in the regional context and the Olona-Bozzente-Lura River Contract (in the box) (Source ERSAF Lombardia)

intensity and intentionality, indicates an interest in rivers and their possible role within urban planning choices. In particular, giving back space to rivers apply to many areas of transformation recognized and regulated in the PGTs, often legitimizing drastic redevelopment interventions on disused or underused areas, proposing again the themes of brownfield redevelopment recalled in the second paragraph of this paper.

Two examples in the River Olona-Bozzente-Lura Contract, relating to the municipalities of Garbagnate Milanese and Saronno, return the efforts made and the results-still very partial-of the introduction of river redevelopment measures in municipal urban planning tools.

The Municipality of Garbagnate Milanese, for example, has introduced in some Areas of transformation ${ }^{26}$ of the Plan Document, specific actions that directly relate to the presence of watercourses (Torrente Guisa and Canale Villoresi) focusing more on the opportunity to strengthen their role both for landscape and fruition (e.g. by creating

\footnotetext{
${ }^{26}$ According to the urban planning regulations in Lombardy, the"Piano di Governo del Territorio" (PGT) is divided into three components: the Plan Document, the Service Plan and the Rules Plan.
} 


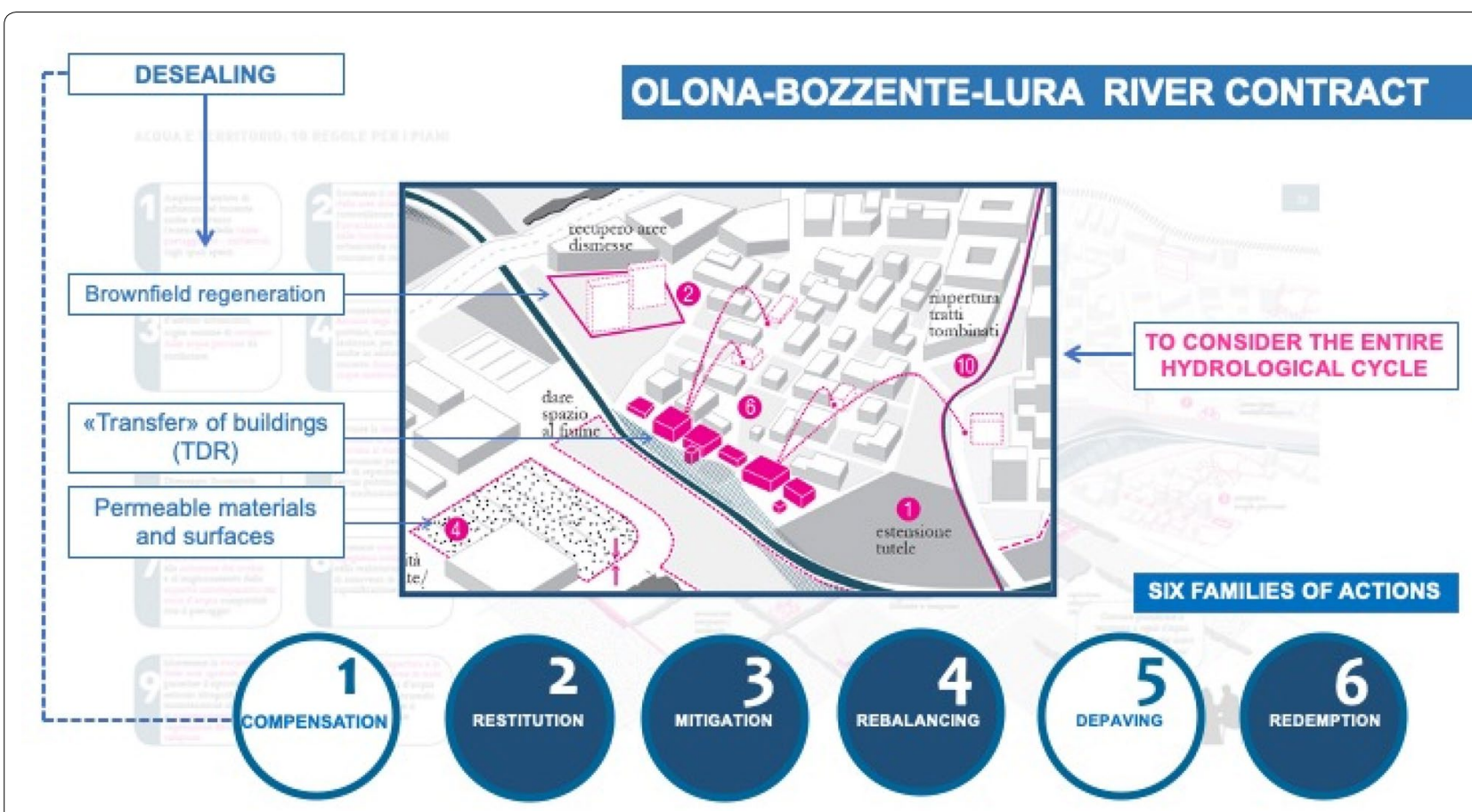

Fig. 4 Example of planning tool indications: recovery of the filtering capacity of the floors; re-naturalization of watercourses; demolition or transfer of buildings (Source: Olona-Bozzente-Lura River Contract/elaboration of the Authors)

new spaces for the collectivity and slow mobility). The issue of de-sealing, in this case, can be found in the widening of the areas of the relevance for the river, with the aim of-in a specific case (AT.R2)-bringing the Guisa river to the surface after it was put underground (as a result of the industrial settlement subject to redevelopment). However, in Garbagnate as in other contexts of this territory, the river has been treated with a generalized point of view that did not lead to the specific characterization of the areas of transformation.

Different was the approach used by the Municipality of Saronno which, in the plan approved in 2013, identified along the Lura river specific "Urban reorganization and regeneration areas", including both disused and underused spaces, and public property areas. The main and explicit objective of the implementation of these projects is the improvement of the relationship between the urban system and the river through a rearrangement of the settlement structure aimed at creating an area for public use along the riverbank, including the renaturalization of the riverbanks.

\section{Conclusions}

Based on the considerations proposed in the previous paragraphs which stressed the need to consider the entire hydrological cycle within a wider geographical perspective, the need to implement desealing projects into different spatial conditions emerges. This kind of operations, as described in paragraphs 2 and 3, will have to relate with the real characterization and composition of the urban rivers' territory, dealing with the following issues:

- The "river space", providing for the renaturalization of the entire Osection of the riverbed removing concrete and physical structures; with these actions it is possible to intervene directly on the river reactivating part of the ecological and biological values lost with the transformation, moreover, the renaturalization is an effective response to flood phenomena as it improves the hydraulic safety of the territories by increasing the flood holding capacity (Fusco 2014: 71);

- The "land taken from the river", that is the spaces (often occupied by abandoned or underused buildings) along the water course that have been waterproofed during urban growth due to the creation of built-up areas designed to ensure different functions. In this case it is a question of intervening through initiatives aimed at restoring space to the river or, in more extreme cases, restoring the channel geometry in a floodplain (Delibas and Tezer 2017);

- The "sponge-like city", that is the part of the urban fabric inside the river basin, not necessarily linked to the river through a spatial contiguity relation- 
ship, where sustainable urban drainage measures can be implemented to improve the water management. In this vast territory, desealing can involve and combine different types of actions and spaces (public or private), e.g. it can be applied in brownfield redevelopment interventions or in those intended to increase the permeability of public open spaces (e.g. parking lots).

The River Contracts, due to their multi-thematic and multiscalar nature and their ability to build a dialogue between territorial actors, can happen in the territories compromised by soil sealing processes suggesting different actions on different spatial contexts. The theme of the redevelopment of urban rivers that are emerging in the Milan area has series of characteristics that bring it closer to the considerations just outlined. In recent years, within the Olona-Bozzente-Lura River Contract, slow and partial rivers restoration actions have been implemented, with the aim of: (i) strengthening ecological conditions; (ii) enhance the fruition (pedestrian-cycle); (iii) improve flood safety. River environment restoration works carried out, often aligned with the objectives of the River Contracts, have benefited from regional funding and inter-institutional support (Municipalities, Lura regional Park, ERSAF, etc.).

The different indications proposed in this tool underline the need to intervene on different types of spaces, including both the elements that directly compose the river (riverbed and floodplain) and the private (brownfield) or public (e.g. roads and parking areas) waterproofed areas within the river basin area. Without a clear recognition of the three territorial sections previously presented, this river contract accepts the opportunity to suggest different interventions related to this distribution, involving the different territorial actors according to a common vision.

However, the restoration works are often partial both in terms of territorial extension (compared to the complexity and extent of the river system) and in terms of type (only focusing on single issues such as hydraulic risk). Those interventions concern certain specific themes destined, for example, to the re-naturalization of river areas or the realization of hydraulic engineering works. These actions were promoted and implemented on limited areas and within singular municipal administrations, with the economic support of public funding (often from the Lombardy Region). Therefore, a holistic approach, inherent in the nature of the River Contract (and now consolidated in the scientific literature and the international best practices) has not yet been achieved in practice.
The River Contracts, although configured as multithematic scenarios and based on the construction of "resilient river communities" (therefore characterized by a significant cultural function), shows a lack of effectiveness due to the distance between the strategic dimension and the binding territorial government tools. Concerning this topic of territorial scale, there is a limit in the Italian legislation relative to the preponderant role attributed to the municipal-level urban planning tools. Within this operating framework, the reference to the municipalities is a necessary condition to ensure the full implementation of the River Contracts strategies.

The analysis of the urban planning activities of these medium-sized cities are characterized by the difficult coexistence between rivers and urban spaces, underlines the slow and partial (in some cases completely absent) transposition of the River Contracts recommendations. Concerning the need of giving back "space to rivers" through the reconciliation between urban areas and watercourses (the main objective of River Contracts), within municipal policies the implementation of projects for the redesign of previous settlement patterns (brownfield) is a common practice. These projects often cover areas, even private ones, located along the course of the rivers, within a policy of urban regeneration and subtraction aimed at increasing the level of soil permeability. Public finance difficulties, sometimes combined with private property, limit these operations to "circumscribed projects," which involve private stakeholders and capital. In a historical phase characterized by the "longest structural crisis of the capitalist economies" (Pasqui 2017), the "traditional approach"-by which investment costs and the assessment on the need for implementation of interventions are transferred to private operators-shows its limitations. In summary, the difficult implementation of these regeneration projects in the Lombardy context, as well as at a national level, highlights the effects of both a regulatory framework with problems to implement policies at a territorial scale and the difficulties of a public intervention increasingly delegated to compensation project deriving from urban transformation measures promoted by private operators.

In the Italian regulatory context, and specifically in the analysed Lombardy Region, the assumption of the River Contract as an instrument of policies on a territorial scale represents a crucial reference for guiding the choices of soil planning at the local level. The weaknesses recognizable in the current situation are to be recognized in at least three issues: (i) the land use regulatory regime, which gives municipalities a very broad competence, in a metropolitan reality with high administrative fragmentation (the River Contract Olona-Bozzente -Lura analysed involves 60 municipalities), makes the choices 
very difficult; (ii) the weakness of public finance makes it difficult to direct public funding to large-scale projects. This weakness allows municipalities to have limited viewing and manoeuvring space, within urban transformation projects activated with private capital; (iii) a more complex cultural theme of the acquisition of awareness and responsibility by institutions and citizens about the centrality of safety and environmental and landscape qualification policies aimed at river environments and the water-city relationship.

Finally, it should be remembered that a Law approved by the Lombardy Region in $2016^{27}$ and the resulting Regulation ${ }^{28}$ in the following year, brought new attention to some issues covered by river contracts. The interest of this complex initiative concerned, for example, the need to rethink the relationship between urbanized areas and the water cycle, considering different types of actions and spaces (e.g. private urban areas affected by re-development interventions). This Law not only highlighted the critical issues related to soil sealing processes, but also introduced the principles and mechanisms for Low-Impact Developments within urban planning tools. It is too early to understand what the benefits introduced by the Law can be, given the slow adaptation mechanism of urban planning tools foreseen, but its approval has imposed a new reflection on the issue of water through a solicitation that has come especially to local administrations that the Lombard experience of river contracts continues to recognize as central subject.

\section{Acknowledgements}

Not applicable.

\section{Authors' contributions}

"Introduction: a necessary reconciliation between water and city" and "Background: re-writing the city and re-covering the land" sections by FA. "A path for river rehabilitation", "Disputed spaces: themes and projects" and "Conclusions" sections by EG. The authors read and approved the final manuscript.

\section{Funding}

The study was funded by Department of Engineering and Applied Sciences University of Bergamo.

\section{Availability of data and materials}

The data supporting the conclusions are included within the article.

\section{Ethics approval and consent to participate}

Not applicable.

\section{Consent for publication}

Not applicable.

\section{Competing interests}

The authors declare no competing interests.

\footnotetext{
27 Regional Law No 4 of 2016 "Review of regional legislation on soil protection, prevention and mitigation of hydrogeological risk and management of watercourses".

28 Regional Regulation No 7 of 2017.
}

Received: 14 December 2019 Accepted: 6 June 2020

Published online: 15 June 2020

\section{References}

Adobati F, Garda E (2019) Land return: le azioni di de-sealing per il recupero del suolo nei contesti urbani. Territorio 90:154-162

Ahiablame LM, Engel BA, Chaubey I (2012) Effectiveness of low impact development practices: literature review and suggestions for future research. Water Air Soil Pollut 223(7):4253-4273

Albrechts L (2004) Strategic (spatial) Planning Re-examined. Environ Plan B Plan Design 31:743-758

Artmann M (2014) Assesment of soil sealing management responses, strategies, and targets toward ecologically sustainaible urban land use management. Ambio 43:530-541

Atkinson G, Doick KJ, Burningham K, France C (2014) Brownfield regeneration to greenspace: delivery of project objectives for social and environmental gain. Urban For Urban Green 13:586-594

Balducci A, Fedeli V, Pasqui G (2016) Strategic planning for contemporary urban regions: city of cities: a project for Milan. Routledge, New York

Berruti G, Moccia FD (2016) Planning knowledge and process for strategies of participatory river contracts. In: Ingaramo R, Voghera A (eds) Topics and methods for urban and landscape design. Urban and landscape perspectives. Springer, Cham

Bocchi S, La Rosa D, Pileri P (2012) Agro-ecological analysis for the EU water framework directive: an applied case study for the river contract of the Seveso Basin (Italy). Environ Manage 50:514-529

Boeri S, Lanzani A, Marini E (1993) II territorio che cambia. Ambienti, paesaggi e immagini della regione Milanese. Abitare Segesta, Milano

Bolocan Goldstein M (2009) Geografie milanesi. Politecnica, Santarcangelo di Romagna

Bouma J (2006) Soil functions and land use. In: Certini G, Scalende R (eds) Basic concepts and future challenges. University Press, Cambridge

Brears RC (2018) Blue and green cities. The role of blue-green infrastructure in managing urban water resources. Palgrave Macmillan, London

Brown RR, Keath N, Wong THF (2009) Urban water management in cities: historical, current and future regimes. Water Sci Technol 59:847-855

Brun A (2010) Les contrats de rivière en France: un outil de gestion concertée de la ressource en local. In: Schneier-Madanes G (ed) L'eau mondialisée. La gouvernance en question, Éditions La Découverte, Paris

Brun A (2014) France's water policy: the interest and limits of river contracts. In: Schneier-Madanes G (ed) Globalized water: a question of governance. Springer, Dordrecht

Brun A, Marette S (2003) Le bilan d'un contrat de rivière: le cas de la Reyssouze. Économie rurale 275:30-50

Buoro M (2019) Le infrastrutture paesaggistiche come strumento di rigenerazione urbana. In: Falqui E (ed) Spazi liquidi e paesaggi ibridi. Didapress, Firenze

Carter JC (2007) Spatial planning, water and the Water Framework Directive: insights from theory and practice. Geogr J 173:330-342

Casti E (2013) Cartografia Critica. Guerini Scientifica, Milan

Chiesa S (2005) L'acqua generatrice e modificatrice delle morfologie terrestri. In: Pagani L, Tosi A (eds) Acqua e paesaggio. Sestante Edizioni, Bergamo

Chiesura A (2004) The role of urban parks for sustainable city. Landsc Urban Plan 68:129-138

Cho M (2010) The politics of urban nature restoration. The case of Cheonggyecheon restoration in Seoul. IDPR 2:145-165

Choukr-Allah R, Ragab R, Rodriguez-Clemente R (eds) (2012) Integrated water resources management in the Mediterranean region. Springer, Dordrecht

Clementi A, Dematteis G, Palermo PC (1996) Le forme del territorio italiano. Laterza, Roma-Bari

Clewell AF, Aronson J (2006) Motivations for the restoration of ecosystems. Conserv Biol 20:420-428

Costanza R, d'Arge R, de Groot R, Farber S, Grasso M, Hannon B, Limburg K, Naeem S, O'Neill R, Paruelo J, Raskin RG, Sutton P, van den Belt M (1997) The value of the world's ecosystem services and natural capital. Nature 387:253-260

D'Ambrosio V, Leone MF (2015) Climate change risks and environmental design for resilient urban regeneration. Napoli est pilot case. J Technol Archit Environ 10:130-140 
Dalmasso E (1972) Milano capitale economica d'Italia. Franco Angeli, Milano Darby S, Sear D (2008) River restoration. Managing the uncertainty in restoring physical habitat. Wiley, Hoboken

De Groot R, Wilson MA, Boumans R (2002) A typology for the classification, description and valuation of ecosystem functions, goods and services. Ecol Econ 41:393-408

Delibas M, Tezer A (2017) 'Stream Daylighting' as an approach for the renaturalization of riverine systems in urban areas: Istanbul-Ayamama Stream case. Ecohydrol Hydrobiol 7:18-32

Depietri Y, Renaud FG, Kallis G (2012) Heat waves and floods in urban areas: a policy-oriented review of ecosystem services. Sustain Sci 7:95-107

Dietz ME (2007) Low impact development practices: a review of current research and recommendations for future directions. Water Air Soil Pollut 186:351-363

EEA (2006) Urban sprawl in Europe: the ignored challenge. Office for Official Publications of the European Communities, Luxembourg

EU (2012) Guidelines on best practice to limit, mitigate or compensate soil sealing. Publications Office of the European Union, Luxembourg

EU (2016) No net land take by 2050? Future brief 14. Publications Office of the European, Luxembourg

Ferreira CSS, Walsh RPD, Ferreira AJD (2018) Degradation in urban areas. Curr Opin Environ Sci Health 5:19-25

Fini A, Frangi P, Mori J, Donzelli D, Ferrini F (2017) Nature based solutions to mitigate soil sealing in urban areas: results from a 4-year study comparing permeable, porous, and impermeable pavements. Environ Res 156:443-454

Foley JA, Defries R, Asner GP, Barford C, Bonan G, Carpenter SR, Chapin FS, Coe MT, Daily GC, Gibbs HK, Helkowski JH, Holloway T, Howard EA, Kucharik CJ, Monfreda C, Patz JA, Prentice IC, Ramankutty N, Snyder PK (2005) Global consequences of land use. Science 309:570-574

Francis RA (2012) Positioning urban rivers within urban ecology. Urban Ecosyst 15(2):285-291

Francis RA, Lorimer J (2011) Urban reconciliation ecology: the potential of living roofs and walls. J Environ Manage 92:1429-1437

Fusco P (2014) Introduzione. In: Toppetti F (ed) Nuovi temi di paesaggio. Franco Angeli, Milano

Garda E, Adobati F (2018) Recuperare terra: cinque contesti applicativi di politiche di de-sealing. Urbanistica informazioni 278:160-164

Gardi C, Panagos P, Van Liedekerke M, Bosco C, De Brogniez D (2015) Land take and food security: assessment of land take on the agricultural production in Europe. J Environ Planning Manage 58:898-912

Gibelli G, Gelmini A, Pagnoni E, Natalucci F (2015) Manuale di drenaggio urbano. ERSAF, Milano

Gonzalez M, de Jalon DG, Roman M (2012) River restoration in Spain. Environ Manage 50:123-139

Grant G (2012) Ecosystem services come to town: greening cities by working with nature. Wiley, Hoboken

Grant G (2016) The water sensitive City. Wiley, Hoboken

Grimm NB, Grove J, Pickett STA, Redman CL (2000) Integrated approaches to long-term studies of urban ecological systems. Bioscience 50:571-584

Haase D (2009) Effects of urbanization on the water balance-a long-term trajectory. Environ Impact Assess Rev 29:211-219

Hung Y, Aquino G, Waldheim C, Gueze A, Skjonsberg M (2011) Landscape infrastructure. Birkhauser, Basel

Jaspers FGW (2003) Institutional arrangements for integrated river basin management. Water Policy 5:77-90

Kabish N, Qureshi S, Haase D (2015) Human-environment interactions in urban green spaces-a systematic review of contemporary issues and prospects for future research. Environ Impact Assess Rev 50:25-34

Knoll M, Lubken U, Schott D (2017) River lost. River Regained. University of Pittsburgh Press, Pittsburgh

Lanzani A (2013) Città territorio urbanistica tra crisi e contrazione. Franco Angeli, Milan

Lanzani A (2014) Un progetto per l'urbanistica, una urbanistica per riformare il paese. In: Russo M (ed) Urbanistica per una diversa crescita. Donzelli, Rome

Legambiente (2016) Ecosistema rischio. Indagine sulle attività delle amministrazioni locali per la mitigazione del rischio idrogeologico. Legambiente, Rome
Lemmons J, Victor R (2008) Uncertainty in river restoration. In: Darby S, Sear $D$ (eds) River restoration: managing the uncertainty in restoring physical habitat. Wiley, Hoboken

Magnaghi A (ed) (1995) Bonifica, riconversione e valorizzazione ambientale del bacino dei fiumi Lambro, Seveso e Olona. INU Edizioni, Rome

Magnaghi A (2008) I contratti di fiume: una lunga marcia verso nuove forme integrate di pianificazione territoriale. In: Notiziario dell'Archivio Osvaldo Piacentini 1, Reggio Emilia, pp 89-98

Mariarinaldi B (2007) Landscapes of metropolitan hedonism The Cheonggyecheon Linear Park in Seoul. J Landsc Archit 2:60-73

Masseroni D, Massara F, Gandolfi C, Bischetti GB (2018) Manuale sulle buone pratiche di utilizzo dei sistemi di drenaggio urbano sostenibile. EcoComunicazione, Verona

Mazza L (2013) If strategic planning is everything. Maybe it's nothing. disP 194:40-42

Miller JD, Hutchins M (2017) The impacts of urbanisation and climate change on urban flooding and urban water quality: a review of the evidence concerning the United Kingdom. J Hydrol Region Stud 12:345-362

Milly PCD, Wetherald RT, Dunne KA, Delworth TL (2002) Increasing risk of great floods in a changing climate. Nature 415:514-517

Molle F (2006) Planning and managing water resources at the river-basin level: emergence and evolution of a concept (IWMI Comprehensive Assessment Research Report 16). International Water Management Institute, Colombo

Nickel D, Schoenfelder W, Medearis D, Dolowitz DP, Keeley M, Shuster W (2013) German experience in managing stormwater with green infrastructure. J Environ Plan Manag 57(3):403-423

Nienhuis PH, Leuven REW (2001) River restoration and flood protection: controversy or Synergism? Hydrobiologia 444:85-99

Pagani L (2004) Premesse. In: Pagani L (ed) Corsi d'acqua e aree di sponda: per un progetto di valorizzazione. Sestante edizioni, Bergamo

Pagani L (2007) La Morla nel paesaggio bergamasco: riferimenti storicogeografici. In: Ferlinghetti R (ed) Quaderni 16. II torrente Morla. Caratterivalori-prospettive. Sestante edizioni, Bergamo

Pasqui G (2017) Urbanistica oggi. Piccolo lessico critico, Donzelli

Pauleit S, Ennos R, Golding Y (2005) Modeling the environmental impacts of urban land use and land cover change - a study in Merseyside, UK. Landsc Urban Plan 71:295-310

Perini K, Sabbion P (2016) Green-blue infrastructure in urban areas, the case of the Bronx River (NYC) and Paillon (Nice). TECHNE 11:97-103

Perini K, Sabbion P (2017) Urban Sustainability and River Restoration. Wiley Blackwell, Oxford

Perry RW, Lindell K (1997) Principles for managing community relocation as a hazard mitigation measure. J Contingencies Crisis Manage 5:49-59

Petts G, Heathcote J, Martin D (2002) Urban rivers. Our inheritance and future. IWA, London

Pickett STA, Cadenasso ML, Grove JM, Nilon CH, Pouyat RV, Zipperer WC, Costanza R (2001) Urban ecological systems: linking terrestrial ecological, physical, and socio-economic components of metropolitan areas. Annu Rev Ecol Syst 32:127-157

Pileri P (2007) Compensazione ecologica preventive. Principi, strumenti e casi. Carocci, Rome

Prominski M, Stokman A, Zeller S, Stimberg D, Voermanek H, Bajc K (2012) River, space, design: planning strategies, methods and projects for urban rivers. Birkhauser, Basel

Public Utilities Board (2018) Active, beautiful, clean waters. Design guidelines. PUB, Singapore

Rahaman MM, Varis O (2005) Integrated water resources management: evolution, prospects and future challenges. Sustainabil Sci Pract Policy 1(1):15-21

Ronchi S (2018) Ecosystem services for spatial planning. Innovative approaches and challenges for practical applications. Springer, Cham

Rosenzweig ML (2003) Win-win ecology: how the earth's species can survive in the midst of human enterprise. Oxford University Press, New York

Rosillon F, Lobet J (2008) Transboundary river contract Semois-Semoy between Belgium (Wallonia) and France. In: Meire P, Coenen M, Lombardo C, Robba M, Sacile R (eds) Integrated water management. Springer, Dordrecht

Rosso R (2017) Bombe d'acqua. Alluvioni d'Italia dall'Unità al terzo millennio. Marsilio Editori, Padova 
Sancy M (2008) Quelques réflexions sur l'utilisation des approches volontaires et le droit International de l'environnement. In: Hervé-Fournereau N (ed) Les approches volontaires et le droit de l'environnement. Presses Universitaires de Rennes, Rennes

Sartorio F (2005) Strategic spatial planning. disP 162:26-40

Scaduto ML (2016) River contracts and integrated water management in Europe. Springer, Dordrecht

Scalenghe R, Marsan FA (2007) The anthropogenic sealing of soils in urban areas. Landsc Urban Plan 90:1-10

Stanghellini S (2010) Riflessioni e proposte per una perequazione sostenibile. In: Perrone C, Zetti I (eds) II valore della terra. Teoria e applicazioni per il dimensionamento della pianificazione territoriale. Franco Angeli, Milan

Sturla P, Di Chiara G (2017) Mitigazione del rischio idraulico ed adattamento ai cambiamenti climatici: metodi, alternative e criticità. In: Talia M (ed) Un futuro affidabile per la città. Planum Publisher, Milan

Teodosiu C, Barjoveanu G, Teleman D (2003) Sustainable water resources management. 1. River Basin Management and the EC water framework directive. Environ Eng Manage J 2(4):377-379

Terranova A (ed) (1997) II progetto della sottrazione. Groma Quaderni, Rome
Tobias S, Conen F, Duss A, Wenzel L, Buser C, Alewell C (2018) Soil sealing and unsealing: state of the art and examples. Land Degrad 29:2015-2024

Voghera A (2015) River contracts in Italy. An experience for river management. Recent advances in environmental and earth sciences and economics, pp 531-362. http://www.inase.org/library/2015/zakynthos/bypaper/ ENG/ENG-58.pdf. Accessed May 2020

Vurro M, Giuliano G, Passino R (2007) Quali impatti si prospettano per le risorse idriche a seguito dei previsti cambiamenti climatici. Geologi e territorio 3-4:31-38

Wolch JR, Byrne J, Newell JO (2014) Urban green space, public health, and environmental justice: the challenge of making cities 'just green enough'. Landsc Urban Plan 125:234-244

Wratten S, Harpinder S, Cullen R, Costanza R (eds) (2013) Ecosystem services in agricultural and urban landscapes. Wiley, Hoboken

\section{Publisher's Note}

Springer Nature remains neutral with regard to jurisdictional claims in published maps and institutional affiliations.

\section{Submit your manuscript to a SpringerOpen ${ }^{\circ}$ journal and benefit from:}

- Convenient online submission

- Rigorous peer review

- Open access: articles freely available online

- High visibility within the field

- Retaining the copyright to your article

Submit your next manuscript at $\boldsymbol{\nabla}$ springeropen.com 